\title{
NEW CULTURAL HORIZONS: 3D
}

\author{
Ioana MISCHIE \\ I.L. Caragiale National University of Theatre and Film, Scriptwriting, Bucharest, Romania \\ ioana_mischie@yahoo.com
}

\begin{abstract}
Nowadays, we are witnessing new horizons in the contemporary cinema: the 3D technique's giant step. The question is: is 3D a valid criteria? The filmmaker wants you to live with the characters, offering Cinema an incredible flexibility as a multicultural platform. We have no universal scale at our disposal to measure the quality of a good story, of a memorable film, or even of an innovative technique. It is more a matter of communis opinio: what is generally accepted as good quality. At the start of the film you have to engage the minds and hearts of the audience. It's crucial, it is a hyatus. The presentation is based on individual film analysis, exemplified by interviews with James Cameron (the director of "Avatar"), with Wim Wenders (the director of the 3D documentary "Pina") and as well, will take into consideration a case study focused on how the Romanian public understands 3D.
\end{abstract}

Keywords: 3D, Cinema, New cultural wave, Storytelling

\section{INTRODUCTION}

In his book "The Century", Alain Badiou asks himself : "How many years has century? A hundred years?" Is a century really defined by the number of years or by something more intrinsic than that? His question is, in fact: are our criteria efficient enough? Extrapolating, how can we measure three-dimensionality, culture, new media, digitalization, democracy, fairness or happiness? Which one is our main criteria? Box office? Google searches? Or maybe... something deeply connected to our inner selves, our inner perception, our own cultural imago mundi.

When talking about cinema from the point of view of its technical evolution, more specifically about three-dimensionality it is fitting to begin with a question "Which facet of a diamond do you want to light?" The light being our own analysis, and the facet being certain characteristics that we associate to $3 \mathrm{D}$. Of course, it is tremendously hard, maybe almost impossible to predict the future of 3D, it's even harder to explain the history of this technique, which was invented more than 100 years ago, but despite this it became well-known to the audiences only now. Therefore, it would be the most appropriate to discuss the present time of three-dimensionality, the way we perceive it, imagine it, feel it. How do our attitudes, as both audiences and filmmakers influence 3-D and how does it influence us?

\subsection{The Definition Of 3d As A Hyatus Between History And Evolution}

Nowadays, we are witnessing new horizons in the contemporary cinema: the 3D technique's giant step. The question is: is 3D a valid criteria? The filmmaker wants you to live with the characters, offering Cinema an incredible flexibility as a multicultural platform. We have no universal scale at our disposal to measure the quality of a good story, of a memorable film, or even of an innovative technique. It is more a matter of communis opinio: what is generally accepted as good quality. At the start of the film you have to engage the minds and hearts of the audience. It's crucial, it is a hyatus. 
Stricto sensu, a three-dimensional film or stereoscopic 3D film is a motion picture that enhances the illusion of depth perception. Derived from stereoscopic photography, a regular motion picture camera system is used to record the images as seen from two perspectives, and special projection hardware and/or eyewear are used to provide the illusion of depth when viewing the film. 3-D films are not limited to feature film theatrical releases; television broadcasts and direct-tovideo films have also incorporated similar methods, primarily for marketing purposes, or for what we will define in the next chapter as an "adaptive unconscious" of an audience.

The perceptions are still different. James Cameron, while he's not the first to embrace the technology, he has become its most vocal evangelist, asserting that digital 3-D is now good enough to make it-after sound and color--the third sea change to affect movies affirms: "This really is a revolution". Director Christopher Nolan, instead, doesn't separate very much the techniques, he unifies them: "I think it's a misnomer to call it 3-D versus 2-D. The whole point of cinematic imagery is it's three-dimensional...95\% of our depth cuescome from occlusion, resolution, color and so forth, so the idea of calling a 2 -D movie a "2-D movie" is a little misleading..."

\subsection{The Chronology Of The 3-D Ars Combinatoria}

The history of the 3-d technique is one of the most intricate in the history of cinema.

- In 1894 William Friese Greene files a patent application for a 3D viewing process using two screens side by side, united in the viewer's eye by a cumbersome stereoscope headset. As with all his endeavors, he is ahead of his audience by about 30 years.

- In 1915 the first presentation of 3D films before a paying audience took place at the Astor Theater, New York. The program consisted of three one-reels, the first of rural scenes in the USA, the second a selection of scenes from Famous Players' Jim, the Penman (US '15), with John Mason and Marie Doro, and the third the Niagara Falls. The anaglyphic process used, developed by Edwin S. Porter and W.E. Waddell, involved the use of red and green spectacles to create a single image from twin motion picture images photographed $2 \frac{1}{2}$ inches apart. The experiment was not a success. Lynde Denig wrote in Moving Picture World: "Images shimmered like reflections on a lake and in its present form the method couldn't be commercial because it detracts from the plot."

- In 1922, premiered the first 3D feature film, Nat Deverich's 5-reel melodrama Power of Love, starring Terry O'Neil and Barbara Bedford, at the Ambassador Hotel Theater, Los Angeles. The film related the adventures of a young sea captain in California.

- In 1936 was released the first feature-length talkie in 3D, Sante Bonaldo's Nozze vagabonde (Italy), starring Leda Gloria and Ermes Zacconi, which was produced by the Società Italiana Stereocinematografica at the Cinee-Caesar Studios.

- In 1947, the first feature-length talkie in color and 3D was Alexander Andreyevsky's Soyuzdet film production Robinson Crusoe (USSR). The process used, Stereokino, was the first to successfully dispense with anaglyphic spectacles. The most difficult technical problem encountered during the production of Robinson Crusoe was persuading a wild cat to walk along a thin branch towards the camera. After five nights occupied with this one scene, the cameraman succeeded in getting a satisfactory shot. The effect, according to accounts, was riveting, the animal seeming to walk over the heads of the audience and disappear at the far end of the cinema.

- In 1953 is created the first 3D feature with stereophonic sound, Andre de Toth' House of Wax (US). When it was premiered at the Paramount Theater, New York, with 25 speakers, the Christian Science Monitor was moved to deplore the "cacophony of sound hurtling relentlessly at one from all directions". 
- During the 3D boom that began with the low-budget Bwana Devil (US 1952), over 5,000 theaters in the US were equipped to show 3D movies, but the fad was short-lived. 3D production figures were: $1952-1 ; 1953-27 ; 1954-16 ; 1955-1$. Many of these 3D movies were released flat.

- In 1979-85, thanks to the technological run-off from suddenly superfluous industrial research, all manner of sequels, remakes, rip-offs and low-brow entertainment staples benefit from the technological improvement of the 3D format (Friday the 13th Part III in 3D, Jaws 3D, Amityville 3D), but the technique remains disreputable.

- Nonetheless, 3-D films experienced a worldwide resurgence in the 1980s and '90s driven by IMAX high-end theaters and Disney themed-venues. By 2004, 54\% (133 theaters of 248 ) of the IMAX community was 3D-capable. 3-D films became more and more successful throughout the 2000s, culminating in the unprecedented success of $3-\mathrm{D}$ presentations of Avatar in December 2009 and January 2010.

\section{SEMIOTICS OF 3D AS A PERTURBATIO ANIMI}

John Fiske affirms in his study "Introduction to Communication Studies" published in 1982 that communication is a focal point of our life; without communication there is no culture. Therefore, studying communication determines as well studying the culture that integrates it. The question would be, therefore: what is 3D communicating, from a semiotic point of view? Of course, we could find numerous answers by interpreting semiotic theory like the ones elaborated by $\mathrm{T}$. Newcomb, G. Gerbner, H. Lasswell, but the theory that fits the best would be probably Jakobson's interpretation. Because 3D doesn't communicate first of all a message, but rather a feeling, and in order to achieve it uses all the functions defined by Jakobson: referential (contextual information of the story), aesthetic, emotive (self-expression), conative (vocative or imperative addressing of the audiences in our case), phatic (checking channel of communication working- film), metalingual (checking code working- visual storytelling).

\subsection{Semiotic Functions Determining The Evolution Of The Film Industry}

The changing structure of the Film Industry declared a new direction: from oligopolies to conglomerates. During Hollywood's golden age, from the 1920s through the 1940s, five major studios dominated the industry: Paramount, Warner Brothers, MGM, Twentieth Century Fox and RKO. The majors began investing in and distributing smaller, independent films rather than producing their own. Studios used this strategy because it reduced risk; independent productions with smaller budgets didn't have to rely on huge audiences to turn a profit. "Hollywood Renaissance" filmmakers addressed social and political issues head-on and rejected the classical style in favor of more daring approaches borrowed from international art cinema directors. At the loftiest levels of commercial filmmaking, many major, big-budget studio productions, including "Avatar" (James Cameron,2009), "Public Enemies" (Michael Mann 2009) and "Shelock Holmes" (Guy Ritchie,2009) were shot on digital formats rather than on film. With the advent of digital cinematography has come the resurgence of $3 \mathrm{D}$, which, until recently, was considered a quaint, outmoded technology from the 1950s. In 2010 the president of the Motion Picture and 3D hold the promise of a dramatic game change in moviemaking and movie-going" ("Worldwide Box Office")

\section{2."We Don't Buy The Product, We Buy The Package"}

Many film critics and analysts considered 3D a marketing tool, rather than an artistic or a semiotic function or even a "next step" in filmmaking. They seem to define three-dimensionality only as a package for selling the film, designed exclusively for increasing the box-office. The truth is, instead, that high-quality $3 \mathrm{D}$ can really enrich the storytelling in unexpected way, in a much more engaging platform for audiences. Even so, if we don't take into consideration the 
artistic contribution of $3 \mathrm{D}$, the main question would be: what is our criteria, when choosing the "package"?

In his book "Blink", Malcom Gladwell speaks about the adaptive unconscious. The adaptive unconscious is not to be confused with the unconscious described by Sigmund Freud, which was a dark and murky place filled with desired and memories and fantasies that were too disturbing for us to think about consciously. This new notion of the adaptive unconscious is thought of, instead, as a kind of giant computer that quickly and quietly processes a lot of the data we need in order to keep functioning as human beings.

For example, when you walk out into the street and suddenly realize that a truck is bearing down on you, do you have time to think through all your opinions? Of course not. The only way that human beings could ever have survived as a species for as long as we have is that we've developed another kind of decision-making apparatus that's capable of making very quick judgments based on very little information. As the psychologist Timothy D. Wilson writes in his book "Strangers to Ourselves", the mind operated most efficiently by relegating a good deal of high-level, sophisticated thinking to the unconscious, just as a modern jetliner is able to fly on automatic pilot with little or no input from the human "conscious" pilot. The adaptive unconscious does an excellent job of sizing up the world, warning people of dangers, setting goals, and initiating action in a sophisticated and efficient manner.

Whenever we meet someone (or somewhat in the case of a film) for the first time, whenever we react to a new idea (3D, for example), whenever we're faced with making a decision quickly and under stress, we use that second part of our brain. How long, for example, did it take you, when you were in college, to decide how good your professor was? A class? Two classes? A semester? The psychologist Nalini Ambady proved that a person watching a silent two-second video clip of a teacher he or she has never met will reach conclusions about how good that teacher is that are very similar to those of a student who has sat in the teacher's class for an entire semester. That's the power of our adaptive unconscious.

The question is then, when you choose to see a film. How long does it take you?

Malcom Gladwell answers: less than two seconds. In this short amount of time, 3-D could play a pivotal role in the minds of audiences (it happened in the case of "Avatar") or could be diminished, when comparing with other possible "fast criteria" like the trailer, story, actors, director of the film.

\subsection{Avatar- A New Type Of Expresis Verbis}

Avatar is a 2009 American epic science fiction motion capture film (fig.1) written and directed by James Cameron. The story is set in the mid-22nd century: a paraplegic Marine dispatched to the moon Pandora on a unique mission (fig.2) becomes torn between following his orders and protecting the world he feels is his home. 


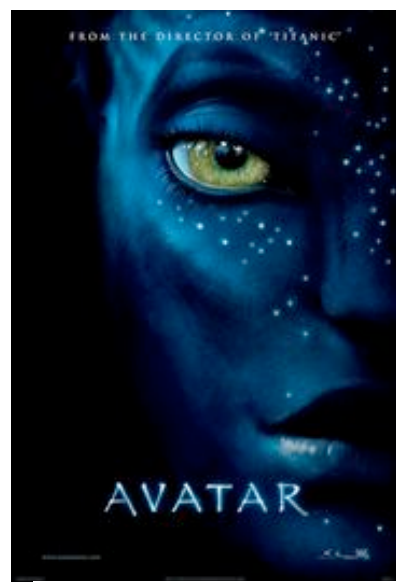

Figure 1. Poster

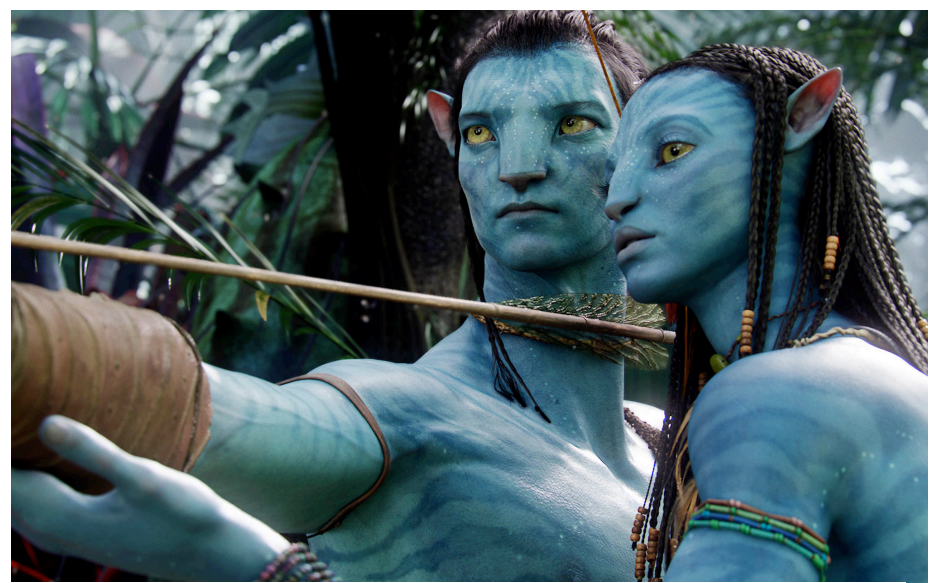

Figure 2. A frame surprising the challenging mission

The development of Avatar began in 1994, when Cameron wrote an 80-page script for the film. Filming was supposed to take place after the completion of Cameron's 1997 film Titanic, for a planned release in 1999, but according to Cameron, the necessary technology was not yet available to achieve his vision of the film. Avatar was officially budgeted at $\$ 237$ million. The film was released internationally in more than 14. 000 screens, for traditional viewing, 3$\mathrm{D}$ viewing and for 4-D experiences in select South Korean theaters. The stereoscopic filmmaking was touted as a breakthrough in cinematic technology.

The film has received various other awards, nominations and honors, The Academy Awards for Art Direction, Cinematography, and Visual Effects, and was nominated for a total of nine, including Best Picture and Best Director. Avatar also won the 67th Golden Globe Awards for Best Motion Picture - Drama and Best Director, and also won the British Academy of Film and Television Arts (BAFTA) award for Production Design and Special Visual Effects. Before launching it, some box office analysts were skeptical but there were also few of them who estimated that the film would be a box office success. "The holy grail of 3-D has finally arrived" said an analyst for Exhibitor Relations. "This is why all these 3-D venues were built: for Avatar." Cameron tried to engage his audience at the maximum level: "We owe them (audiences) a good time. We owe them a piece of good entertainment. [...] If I can just get 'em in the damn theater, the film will act on them in the way it's supposed to, in terms of taking them on an amazing journey and giving them this rich emotional experience."

\subsubsection{Strategy: "Repeated Business" as a Box-office Crescendo}

Cameron was aware of the sentiment that Avatar would need significant "repeat business" just to make up for its budget and achieve box office success, and believed Avatar could inspire the same "sharing" reaction as Titanic. He said that the film worked because, "When people have an experience that's very powerful in the movie theatre, they want to go share it. They want to grab their friend and bring them, so that they can enjoy it. They want to be the person to bring them the news that this is something worth having in their life."

Brandon Gray, president of Box Office Mojo, believed in the film's chances of becoming the highest-grossing film of all time, though he also believed it was too early to surmise because it had only played during the holidays. He said, "While Avatar may beat Titanic's revenue record, it will be tough, and the film is unlikely to surpass Titanic in attendance. Ticket prices were about $\$ 3$ cheaper in the late 1990s." Still, the 3-D appeal made the magic happened. Though analysts have been unable to agree that Avatar's success is attributable to one primary factor, several explanations have been advanced. First, January is historically "the dumping ground for the year's 
weakest films", and this also applied to 2010. Cameron himself said he decided to open the film in December so that it would have less competition from then to January. Titanic capitalized on the same January predictability, and earned most of its gross in 1998.

Undoubtedly, marketing the film as a "novelty factor" helped. Fox positioned the film as a cinematic event that should be seen in the theatres. "It's really hard to sell the idea that you can have the same experience at home" stated David Mumpower, an analyst at BoxOfficeProphets.com. Films in 3-D accumulated \$1.3 billion in 2009, according to Variety, "a threefold increase over 2008 and more than $10 \%$ of the total 2009 box-office gross". The increased ticket price - an average of $\$ 2$ to $\$ 3$ per ticket in most markets - helped the film.

Likewise, Entertainment Weekly attributed the film's success to 3-D glasses, but also to its "astronomic word-of-mouth". Gray said Avatar having no basis in previously established material makes its performance remarkable and even more impressive. "The movie might be derivative of many movies in its story and themes," he said, "but it had no direct antecedent like the other topgrossing films: Titanic (historical events), the Star Wars movies (an established film franchise), or The Lord of the Rings (literature). It was a tougher sell ..."

\subsubsection{Film Critics Reactions}

Review aggregator Rotten Tomatoes reports that $83 \%$ of 275 professional critics have given the film a positive review, with a rating average of 7.4 out of 10 . As a consensus the critics agreed that it might be more impressive on a technical level than as a piece of storytelling, but Avatar reaffirmed James Cameron's singular gift for imaginative, absorbing filmmaking. Richard Corliss of Time magazine thought that the film was, "the most vivid and convincing creation of a fantasy world ever seen in the history of moving pictures." CinemaScore polls conducted during the opening weekend revealed the average grade cinemagoers gave Avatar was A on an $\mathrm{A}+$ to $\mathrm{F}$ scale. Every demographic surveyed was reported to give this rating. These polls also indicated that the main draw of the film was its use of 3-D.

James Berardinelli, film critic for ReelViews, praised the film and its story, giving it four out of four stars he wrote, "In 3-D, it's immersive- but the traditional film elements-story, character, editing, theme, emotional resonance, etc.-are presented with sufficient expertise to make even the 2-D version an engrossing two and a half-hour experience." Avatar even received compliments from filmmakers, with Steven Spielberg praising it as "the most evocative and amazing science-fiction movie since Star Wars". On the other hand, many filmmakers, like Duncan Jones for example, considered it way too predictable.

\section{THE FIRST 3D DOCUMENTARY "PINA" BY WIM WENDERS}

Another case-study is the very first 3D documentary of our times. Premiered in 2011 at the Berlinale International Film Festival, Pina is a feature-length dance film in 3D with the ensemble of the Tanztheater Wuppertal Pina Bausch, featuring the unique and inspiring art of the great German choreographer who died in the summer of 2009. "Pina" is a film for Pina Bausch by Wim Wenders. He takes the audience on a sensual, visually stunning journey of discovery into a new dimension: straight onto the stage with the legendary ensemble and follows the dancers out of the theatre into the city and the surrounding areas of Wuppertal- the place which for 35 years was the home and center for Pina Bausch's creativity. 


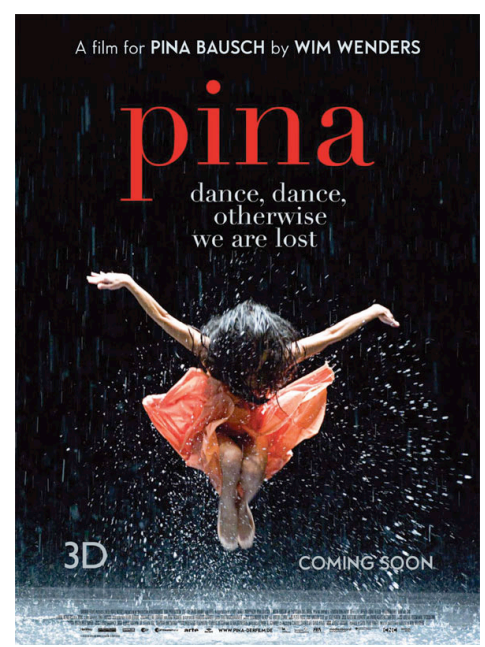

Figure 3. Film Poster

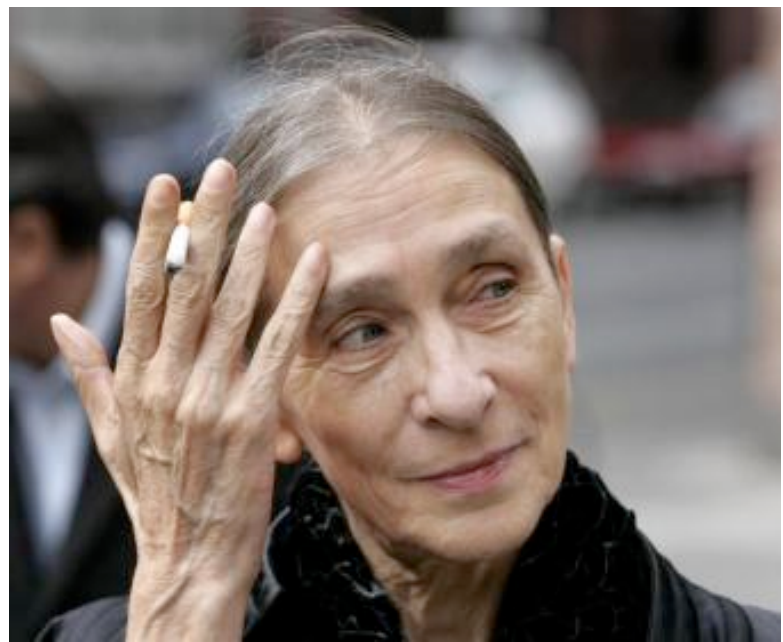

Figure 4. Pina Bausch (portrait)

Using the choreographies which had been jointly selected- "Café Muller", "Le Sacre du prientemps", "Vollmond" and "Kontakthof", and using some images and audio files of her life as well as 3D recordings of individual ensemble members of the Tanztheater Wuppertal who in spring of 2010 danced personal memories of the precise, critical and loving nature of their great mentor. With the latest possibilities created by digital 3D technology, Wim Wenders found the aesthetic means to bring the unique plasticity and emotional expressiveness of Pina Bausch's innovative Tanztheatre to the cinema screen.

Only now can the dimension of the space could be reproduced in the cinema. It is the dimension in which movement and dance take place, and into which the new 3D cinema can take the viewer on a sensual journey of discovery: "Until now movement as such as never touched me. I always regarded it as given. One just moves. Everything moves. How many stories can be told without saying a single sentence?"1 Wim Wenders was deeply impressed and moved when in 1985 he saw for the first time "Café Muller" by choreographer Pina Bausch. Wenders felt that he had not yet found a way to adequately translate Pina Bausch's unique art of movement, gesture, speech and music into film. Over the years, the film concept, which was supposed to be a joint project of Wim and Pina turned into a friendly ritual, almost a running gag, with both artists reminding one another of their plan. "When? " asked always Pina, receiving the answer "As soon as I know how." The "how" was the 3-D technique itself, just that Wenders had to opportunity to bring it to life only after Pina passed away. Alain Derobe, the stereographer of the "Pina" described 3D as an organic instrument "3D tells you to come inside the screen. He wants you to dance with the dancers." He then added "We had an incredible flexibility. 3D made a giant step."

\subsection{Case Study: Romanian Audiences}

In the Romanian Box-Office of 2009 the national box-office changed radically: " Avatar" became the film with the biggest box-office of all times. And this taking into consideration that the ticket for a 3D film was almost double compared to a regular ticket, in a country with a rather diminished film industry, so this came as a total surprise, however it could be motivated mainly due to the 3D technique, and to the existence of the first Imax in Romania, which became a cultural temple of innovation for weeks. After two years, 3D cinemas started to be initiated also

\footnotetext{
${ }^{1}$ Wim Wenders speaking at the ceremony of 2008 Goethe Prize of the city of Frankfurt am Main to Pina Bausch (Excerpt)
} 
in the rest of the country, but this didn't increase the incomes of the other 3-D films considerably. On the second place, but at a long distance is situated "'Ice Age: Dawn of the Dinosaurs" directed by Carlos Saldanha and Mike Thurmeier followed by the 2D film directed by Roland Emmerich, "2012".

\begin{tabular}{|c|c|c|c|c|c|}
\hline Film & $\begin{array}{r}\text { Number } \\
\text { of } \\
\text { weeks }\end{array}$ & $\begin{array}{r}\text { Number } \\
\text { of } \\
\text { spectators }\end{array}$ & Boxoffice & $\begin{array}{l}\text { Spectators } \\
\text { first week }\end{array}$ & $\begin{array}{l}\text { Boxoffice } \\
\text { first week }\end{array}$ \\
\hline 1. Avatar & 38 & 881.718 & $18.614 .408,00$ & 67.200 & $1.527 .705,00$ \\
\hline $\begin{array}{l}\text { Ice Age: } \\
\text { Dawn of } \\
\text { the } \\
\text { Dinosaurs }\end{array}$ & 38 & 337.261 & $6.876 .618,00$ & 65.139 & $1.425 .865,00$ \\
\hline 3.2012 & 11 & 292.018 & $4.844 .214,00$ & 51.562 & $1.001 .118,00$ \\
\hline
\end{tabular}

The year 2010 had another 3-D film as winner "Alice in Wonderland", directed by Tim Burton, but the numbers were much smaller this time, more precisely, almost five times smaller than the winner from the precedent year. On the second place it is situated Christopher Nolan's "Inception" followed by another winner "Shrek forever After", however not in its 3D version this time.

\begin{tabular}{|c|c|c|c|c|c|}
\hline Film & $\begin{array}{r}\text { Number } \\
\text { of } \\
\text { weeks }\end{array}$ & $\begin{array}{r}\text { Number } \\
\text { of } \\
\text { spectators }\end{array}$ & Boxoffice & $\begin{array}{l}\text { Spectators } \\
\text { first week }\end{array}$ & $\begin{array}{l}\text { Boxoffice } \\
\text { first week }\end{array}$ \\
\hline $\begin{array}{l}\text { Alice in } \\
\text { 1. Wonderland }\end{array}$ & 17 & 222.314 & $4.572 .425,00$ & 41.919 & $919.581,00$ \\
\hline $2 .^{\text {Inception }}$ & 21 & 229.152 & $3.801 .450,00$ & 34.469 & $657.337,00$ \\
\hline $\begin{array}{l}\text { Shrek } \\
\text { Forever } \\
\text { 3. After }\end{array}$ & 18 & 158.799 & $3.287 .160,00$ & 44.748 & $1.075 .765,89$ \\
\hline
\end{tabular}

3-D started to decrease step by step, and in 2011, the first place is conquered by a 2-D film "Pirates of the Carribean: On Stranger Tides".

\begin{tabular}{|c|c|c|c|c|c|}
\hline Film & $\begin{array}{r}\text { Number } \\
\text { of } \\
\text { weeks }\end{array}$ & $\begin{array}{r}\text { Number } \\
\text { of } \\
\text { Spectators }\end{array}$ & Boxoffice & $\begin{array}{r}\text { First } \\
\text { Week } \\
\text { Spectators }\end{array}$ & $\begin{array}{r}\text { First Week } \\
\text { Boxoffice }\end{array}$ \\
\hline $\begin{array}{l}\text { Pirates of } \\
\text { the } \\
\text { Caribbean: } \\
\text { On } \\
\text { Stranger } \\
\text { Tides }\end{array}$ & 19 & 346.344 & $6.723 .370,00$ & 83.213 & $1.755 .443,00$ \\
\hline
\end{tabular}




\begin{tabular}{l|l|l|l|l|l|}
$\begin{array}{l}\text { Puss in } \\
\text { 2. Boots }\end{array}$ & 7 & 213.924 & $4.169 .875,68$ & 57.834 & $1.267 .520,74$ \\
\hline Immortals & 10 & 179.031 & $3.764 .560,85$ & 44.914 & $1.021 .508,30$ \\
\hline
\end{tabular}

In the same year, we witness another surprise. The first artistic 3D film, Wim Wender's documentary dedicated to Pina Bauch is situated on the $108^{\text {th }}$ place. Is $3 \mathrm{D}$ a temporary trend or this is just a fluctuation influenced as well by socio-political causes?

$\begin{array}{llllll}\text { 108. Pina } & 12 & 12.929 & 199.455,87 & 2.307 & 41.719,57\end{array}$

Not only in Romania, but also in countries around the world, film industry observers have noted that 2011 has shown a considerable decline in audience interest in 3-D presentation. In view of this trend, there has been box office analysis concluding the implementation of 3-D presentation is apparently backfiring by discouraging people from going to movie theatres at all.

One of the leading proponents of 3-D film and the producer of some of the most critically acclaimed films in this format such as How To Train Your Dragon and Kung Fu Panda 2, Jeffrey Katzenberg, blames oversaturation of the market with inferior films, especially ones photographed conventionally and then digitally processed in post-production for the 3-D format, such as The Last Airbender that have led to audiences concluding the format is not worth the additional expense to see. ${ }^{[54]}$ However at the global box office $63 \mathrm{D}$ films have grossed over $\$ 1$ billion each, 3 from 2011, 2 from 2010 and 1 from 2009.

The influences of 3D and of new techniques in promoting the films had a strong impact on the Romanian New Wave Cinema. It can be easily witnessed from an esthetical and also economical point of view. Just as an example, in 1970 the Romanian film "Mihai Viteazul" was promoted by different film posters in different countries. If we compare them, the story of the film seems to be different from one poster to another: one of them expressed a gaining-confidence-in-yourself theme, the second one seems a passionate love story, and the third one looks like a war film. But all these posters describe the same historical film.

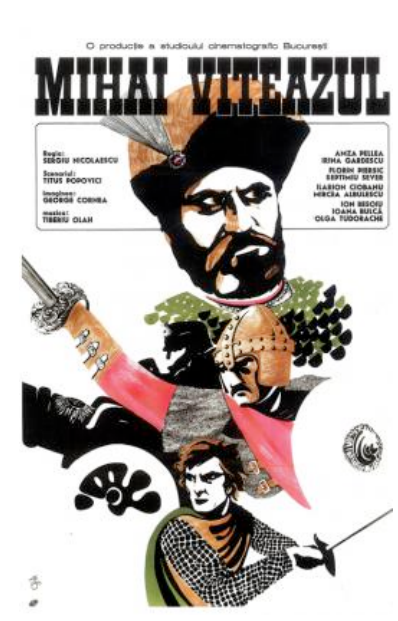

Figure 6. Poster in Romania

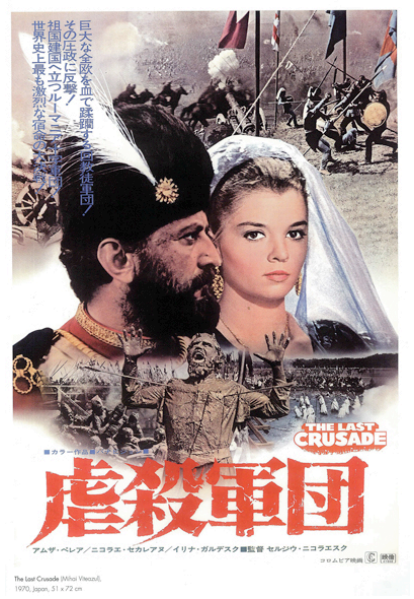

Figure 7. Japan

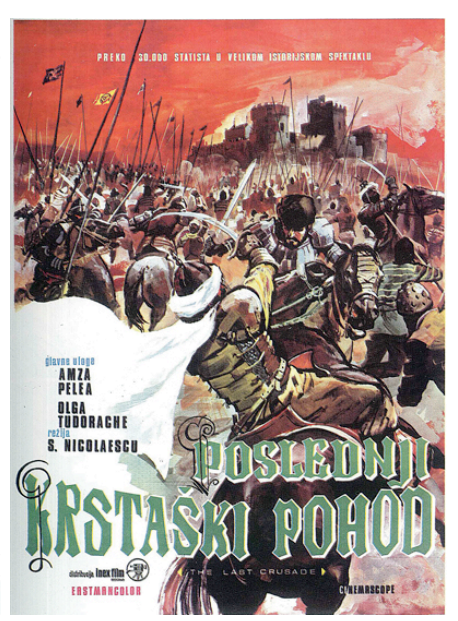

Figure 8. Iugoslavia 
In 2011, the Silver Bear-awarded film "If I want to whistle, I whistle" seems to approach a more concise strategy, being more coherent, and as well being more global as a "local story", a mechanism used as well by 3-D films.

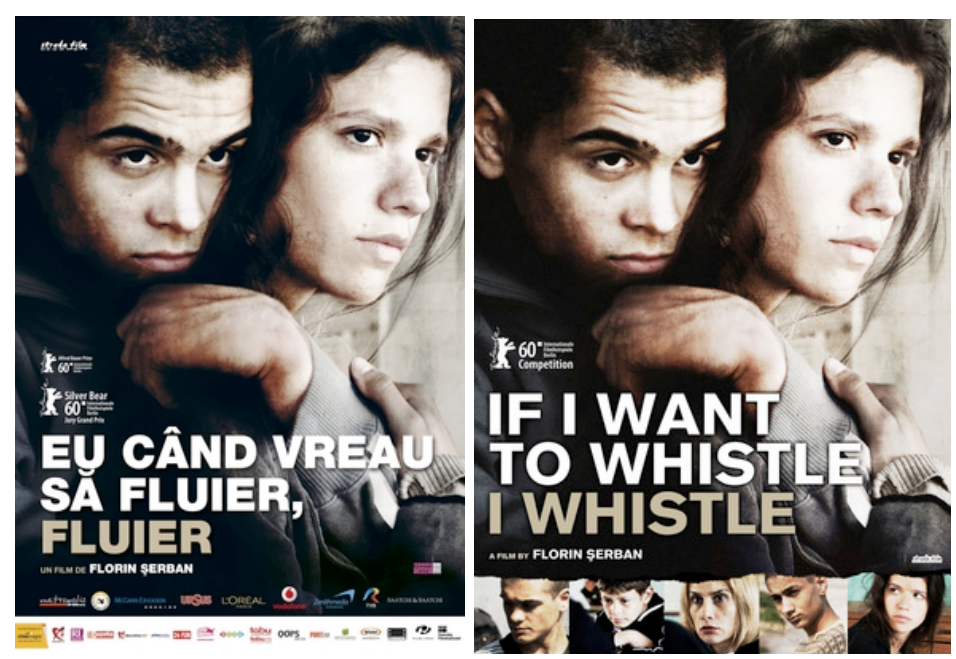

Figure 9. Film poster in Romania and Film poster in U.S.A.

In a world conquered by what Pierre Bourdieu used to call "fast food, fast love, fast thought" we have to stop, to re-evaluate our criteria and to believe in cinema, because cinema integrates the very few quintessential human values: creativity, simplicity, capturing the essence of our times.

\section{REFERENCES}

Badiou, Alain.(2010). "The Century", Cluj: Idea Design\&Print.

Cohen, David S. (September 15, 2009). "Filmmakers like S3D's emotional wallop", Variety. Available at: http://www.variety.com/article/VR1118008671? refCatId=1009.

Gladwell, Malcom. (2005). "Blink, the power of thinking without blinking”, England: Penguin Books, England, page 11;

Patterson, John (August 20, 2009) "A history of 3D Cinema". Available at: http://www.guardian.co.uk/film/2009/aug/20/3d-film-history

Pramaggiore Maria, Wallis Tom. (2011). "Film, a critical introduction", UK: Laurence King Publishing, UK, page 431;

Quittner, Josh (March 18, 2009) "Are 3-D movies ready for their Closeup?" Available at: http://www.time.com/time/magazine/article/0,9171,1886541,00.html\#ixzz1kIwiluXQ

Winters Keegan, Rebecca (January 11, 2007). "Q\&A with James Cameron". Time Magazine. Available at: http://www.time.com/time/arts/article/0,8599,1576622,00.html

Wenders, Wim, speaking at the ceremony of 2008 "Goethe Prize of the city of Frankfurt" am Main to Pina Bausch (Excerpt)

Wilson, Timothy. (2002). "Strangers to ourselves: discovering the adaptive unconscious", Cambridge, Mass.: Harvard University Press 